\title{
Clearing an airfield with wooden logs
}

Florenz Imbiri

It was by using only wooden logs to pound the earth firm and smooth that we managed to clear the airfield in Moanemani, Wisselmeren (present day Paniai). Without the aid of machines and heavy equipment, the work took eight months' time to complete. All the adult residents of the villages around Moanemani, men and women, amounting to approximately six thousand people, joined in to help. They were given their choice of payment: in money or in beads. Yet many of them preferred beads. 'We prefer beads. Just pay us in beads', is how they asked for their wages. A few members of the community were familiar with money, and they asked to be paid in money.

Thus, in that way, they worked with pleasure. Aside from the airfield, we also worked on a whole network of roads from Moanemani to Obano, then from Waghete to Enarotali, again with the work done by villagers, digging and making roads that could eventually be used for vehicles. So, starting from 1959 they were acquainted with cars and airplanes. They were jubilant about the development and progress they achieved.

Upon graduating from OSIBA in $1957 \mathrm{I}$ took a stance and made the decision to work in the interior. I wanted to be together with communities considered to be extremely underdeveloped at that time. I wanted to contribute the knowledge I had gained to the advancement of the people in the interior so that they too could enjoy progress. We were given time to select places to work. I chose the hinterland, that is, the area of Wisselmeren, at the office of the HPB or head of the administrative sub-division headquartered in Enarotali.

The controleur or HPB at the time was Mr. Jan Massink. I was placed under his management as a seconded assistant administrator candidate specifically tasked with making patrols to the villages to bring order, give people an understanding, and encourage them to improve their lives. 
And to expedite these objectives and facilitate relations, in 1957-1958 the government of the Wisselmeren sub division planned to clear the roads and airfield. I was appointed to implement the clearing of the airfield in Moanemani. At the time no kecamatan or district was established yet, but it was to become a district later and I would be appointed as the district head. The work on creating the airfield received assistance from technical personnel of the Rijkswaterstaat (Department of Waterworks).

The level of education of people in the interior generally only reached elementary school. Then, those considered worthy of further schooling were sent to high schools located outside of Wisselmeren, in places such as Merauke and Hollandia. Generally, in Wisselmeren there were only elementary schools, no high schools yet. The exception was one school run by the Roman Catholic mission in Epouto that educated prospective teachers for the elementary schools in villages in the Wisselmeren area.

It was mainly the missions that managed schools in the interior. So schools in Wisselmeren were run by private agencies - in this context, by the Roman Catholic missions and the Protestant zending agency, the Christian and Missionary Alliance (CAMA), today called the Gereja Kemah Injil (Gospel Tabernacle Church). There were not yet any government-run state schools. Indeed, schools throughout Netherlands New Guinea back then tended to be managed by Protestant and Roman Catholic agencies.

\section{THE FIRST PAPUAN TO BECOME CHAIRMAN OF THE DPRD}

In 1960, through a government decree, I was transferred to WaropenAtas, then known as the district of Boven-Waropen. The capital city of the district of Waropen was Wonti. But with the establishment of the new district of Waropen-Atas, the district capital was moved to Barapasi. And there I opened the capital city of Waropen-Atas. Later, during the turbulence surrounding the issue of whether Papua was going to be handed over to Indonesia or become independent, I was appointed as HPB in Serui, and at the same time, served as chairman of the Dewan Perwakilan Rakyat Daerah (DPRD, Regional Council of People's Representatives) of Yapen-Waropen in Serui. Decree no. 15 of the governor of Netherlands New Guinea stipulated my simultaneous 
appointments as chairman of the DPRD of Yapen-Waropen and as HPB for the Yapen-Waropen area.

Thus, in the Dutch period we knew a democratic system. In 1961 the Nieuw-Guinea Raad (New Guinea Council) was established, and then the Streekraden (Regional Councils) on the level of the sub divisions then called onderafdeling, now known as kabupaten (regency/district), such as Yapen-Waropen. And I was the first Papuan appointed to serve as chairman of the DPRD of Yapen-Waropen. The function of the chairman was to accommodate all that was discussed and all the work programmes decided upon by the council of representatives. Programmes in the region were determined by the DPRD together with the HPB, then implemented by the executive, that is, the HPB and his apparatus. The HPB in Yapen-Waropen was Mr. Meijer. When the changeover occurred, I was appointed to replace Mr. Meijer as HPB of Yapen-Waropen. The functions of the council were to prepare or draft regulations on things that could be done in the region, together with the regional government. Thus, it was to plan work or work programmes for the area concerned. Then to create applicable regulations to take effect in the area, so that the people could carry them out in accord with the will of the people of each region.

\section{DIRECT ELECTIONS}

The members of the DPRD were directly elected by the people: first, the villages elected their representatives, and all the representatives of all the villages then elected people they trusted could represent and protect their interests at the DPRD and local government levels. So the members were not elected through political parties, but directly by the people. Because political parties were newly established at that time they did not have much influence on people's choices. So, what is known as democracy truly was implemented directly by the inhabitants of the villages. They chose representatives whom they knew as people they could trust, people who could be expected to accomplish things in the interests of the villagers.

At the provincial level there was the Nieuw-Guinea Raad or Council of People's Representatives of New Guinea. Then, below, at the subdistrict level, were the Streekraden or Regional Councils of People's 
Representatives. The regions that already had such regional councils at that time were Biak-Numfoor, Yapen-Waropen, Fakfak, Merauke, Manokwari, Dafonsoro of Hollandia, Nimboran and Raja EmpatSorong. Meanwhile, the regions that had none yet were Nabire, Baliem, Asmat, Mimika, Tanah Merah and Digul.

During the period of international administration by the United Nations Temporary Executive Authority (UNTEA), all the programmes that had been set up by the past government, that is, the Dutch government, had to continue operating. The making of the road network, the airfield in Yapen-Waropen, and several other work programmes previously set up by the Dutch government continued to be carried out by the organizational structure under UNTEA administration as follows: The secretary general of the UN was the person responsible, and under that person was an administrator acting as governor. Below that there was the division commissioner acting as resident, and further below, subdivision commissioners acting as HPBs. Their jobs were to execute the programmes in progress.

In 1960 the opening of the roads and airfield for communications had already begun. The same was true of marine communications, marked by the opening of the Zeevaartschool (Maritime Academy) and the construction of piers. All of that was intended to expedite communication networks. It was expected that once communications were running smoothly, other forms of developments would occur on their own and progress could be made easily.

Later, the atmosphere changed, because on 1 May 1963, based on the New York Agreement, the UNTEA had to hand Papua, along with the Papuan people, over to the Republic of Indonesia. The Indonesian government initiated new programmes and sent many young people to study outside of Irian Barat. That way they could learn to know and love Indonesia.

THE CONSULTATIVE COUNCIL FOR THE ACT OF FREE CHOICE

To elaborate further on the topic of the regional councils: before the Indonesian government took over, these councils had proper democratic authority. This meant that the council would determine what needed to be done, then the local government, as the executive body, would 
carry out what the council had discussed and decided. In conjunction with the implementation of the Act of Free Choice (1969), the regional councils ceased to exist, were abolished. With the onset of Indonesian rule, all the councils were abolished with the exception of the NieuwGuinea Raad, namely the provincial-level Council of Representatives. In the implementation of the Act of Free Choice it appeared that there were only two councils. That was incompatible with democracy. It was really the Council of Representatives that should have implemented the Act of Free Choice, since it was a body elected by the people. But the Indonesian government instead established the Dewan Musyawarah Penentuan Pendapat Rakyat (Pepera, Consultative Council for the Act of Free Choice), commonly referred to as Dewan Pepera.

In actuality, the function of the UN was to control things until the Act of Free Choice was implemented. But the UN's control function did not continue after the transfer of the administration to Indonesia on 1 May 1963. From that point on, the UN did not maintain control until the implementation of the Act of Free Choice, as per the New York Agreement. It was rather the Indonesian government that held full power.

There was another issue that came up at that time. After Indonesia took over the rule of Papua, Indonesia became embroiled in a confrontation with Malaysia. The confrontation with Malaysia raised objections from the British government. Then Indonesia declared it was withdrawing from the UN in 1965. They withdrew from the UN, so the control function of the UN was no longer in effect. The Indonesian government was not part of the UN from 1965 to 1970. It was only after the Act of Free Choice was over that Indonesia was reinstated a member of the UN. So, during the intervening period, Indonesia was fully entitled to act as it did. Because it was not a member of the UN, it could not be controlled by the UN. As a result, the implementation of the Act of Free Choice was not done in accordance with the terms determined by the UN in the New York Agreement. The Indonesians regulated things themselves. They formed two types of council - the Regional Council of People's Representatives or DPRD for governance, and the Dewandewan Pepera or consultative councils, for the Act of Free Choice. Well, this was not in accord with the democratic principles set forth in the New York Agreement. 
If they had wanted to do it democratically, then the DPRD should have been the body to implement the Act of Free Choice. But because the Indonesian government formed a different body for this, the DPRD was not functional. The Consultative Council for the Act of Free Choice determined that the referendum would not be carried out based on the principle of "one man one vote", but rather through deliberation and consensus. Then it was decided to form councils to implement the Act of Free Choice. The streekraden had been dissolved; the Provincial Council of People's Representatives was bypassed; and the implementation of the Act of Free Choice was left to the councils formed specifically for the Act of Free Choice. This was undemocratic!

\section{UNANSWERED QUESTIONS}

A few major provisions were regulated under the New York Agreement. The first was that the handover of authority over Irian Jaya (then called West Nieuw-Guinea) to the Republic of Indonesia would go through the international agency of the UNTEA. Second: there were basic provisions regarding what was to be exercised by the Papuan people with the acknowledgement of Indonesia and the UN, namely, the right to self determination. The act of self-determination was to be carried out in 1969. The terms of the New York Agreement stated that all adults every adult Papuan or New Guinean, also known as Irianese at that time - must vote. Everyone should be able to vote.

But the implementation was not in accord with the stipulations of the New York Agreement. The right to self determination was exercised only through a sort of committee or council. Well, the council was not representative of all Papuan adults. At the time of implementation, only a few people were selected, a handful of people who did not represent all the people of Papua. Rather, those selected were people whose desires to remain associated with Indonesia were already known, or those who had fought for Indonesia. Since they were the ones picked to serve as members of the Dewan Musyawarah Pemilihan (DMP, Election Consultative Council), the right to self determination was never carried out as stipulated in the New York Agreement. There was no 'one man one vote' election. So what was written in the New York Agreement was not fulfilled. The 'one man one vote' principle was not applied. 
These conditions also affected the implementation of government tasks. Why was it that formerly (in the Dutch government period) elections could be carried out in a democratic manner, but not now? This was confusing. So the people of Papua asked: 'If the established election rules are so good, why change them?' The changes in method stunted the process of democratic growth. So the election process was carried out according to the wishes of the government of the Republic of Indonesia, not according to principles of democracy or the will of the Papuan people.

These questions have continued to influence things until now. Today people are still trying to find out why it was that a free election could not be conducted. After the implementation of the Act of Free Choice, yes, it might be said that the Irianese or Papuans were forced to join Indonesia. In the early years that was an issue, because Papuans were not yet properly familiar with the Indonesian government. Gradually, there has been a transfer of responsibility from Indonesia to the Papuan people since then, but it has not worked as well as it should, which has made the people of Papua indecisive and confused. They ask: 'Why must it be like this?'

This is because, first of all, the Dutch had left Papua in good condition. But then the officials from Indonesia came along. In the economic arena, the goods in the shops were taken away to Indonesia, emptying the shops. So Papuans asked: 'How can this be; why are shops that were once full of goods now empty?' This experience left an imprint on the hearts of the Papuan people.

Second, when the uprising of the Communist Party of Indonesia occurred, a great many people were killed without following any rules. The Papuans asked: 'Why is that?' They said that our incorporation into Indonesia would bring us good, but in reality that was not the case. So Papuans wondered: 'Why?'

Third, after that came an authoritarian government that severely restricted the freedom of the Papuan people. These were the circumstances that drove the Papuans to establish the Organisasi Papua Merdeka (OPM, Free Papua Movement) - something that was strictly forbidden by the Indonesian government. So conditions in society were disturbed. Disturbed and deferred! What had once run so well suddenly changed. And the people asked: 'Why is that?' The authoritarian government prevented people from speaking out freely. Democracy was suppressed. If 
a Papuan spoke out even a bit, the government said: 'Well, he's with the OPM, which is anti-government!' Because they were deemed to be opposing the Indonesian government, many were arrested and many were killed. Some were imprisoned for many years. Some were imprisoned until they died in prison. That is the reality! That is the political side.

Fourth, on the economic side of things, big business entrepreneurs came from Jakarta and took ownership of Papuan adat lands. They completely cut down the tropical forests in Papua, and the money earned was not used to develop Papua, but taken to Jakarta. The adat lands belonged to the Papuan people. Yet when the people wanted to go to their adat lands to cultivate gardens, hunt, and look for food, they were stopped by the entrepreneurs, who had the support of the military and told the Papuans: 'You are no longer entitled to this, it is the right of the entrepreneur.' This put pressure on the Papuans, so they asked: 'Why is this? It is we who live here; it is we who own this land; how can we be restricted like this?' So the freedom of the people to work their own lands was restricted or waived. 'It is not allowed, you are not allowed to make a move.' Land became someone else's property, it now belonged to the entrepreneurs.

Fifth, in the recruitment of government employees, or employees in the business world, not many Papuans were hired. Very few Papuans were hired as office employees, whether in government or private sector offices. Well, this made the Papuans ask: 'Why is this?' In the recruiting process they did not look at the educational qualifications of the job applicant, but rather, advanced their own interests and those of their families first. In the process of hiring employees, whether in local government or the business world, opportunities for Papuans were extremely limited. The restrictions were imposed by non-Papuans. In the field of civil service appointments, non-Papuans knew the dates and months for the appointment of new employees in advance. So they sent this news to their families living in Java, Sumatra, Sulawesi, and elsewhere. They let their families know as an attempt to ensure that their relatives in Papua could secure jobs as officials. They asked their relatives to contact the personnel divisions of the departments concerned in Jakarta, so their relatives in Papua could be hired as civil servants. Thus, the Papuan sons and daughters who applied each year were always sidelined and did not make the quotas for civil servants.

Thus, many Papuans were unemployed, and they asked: 'How is it; this is my region isn't it?' This saddened and disheartened the Papuans. 
They compared their circumstances with those in Makassar. There, if you went into the offices, everyone was Makassarese. There was no mix. The same was true in Java; if you went into the offices, everyone was Javanese. But here, it was not the Papuans who were more numerous, but the newcomers, whether in the government or in the business world.

Conditions like these saddened Papuans and made them ask: 'Why?' Indonesians claimed that they and the Papuans were one nation, but the day-to-day reality was not like that. You could read the feelings of dissatisfaction on Papuan faces, which showed no joy. They were apathetic and kept silent.

It was the same in other fields, for instance, the military. In the 37 years that Papuans have been under Indonesian rule, not many Papuans have served as high-ranking officers in the military. They are just regular soldiers, but there are not so many of these either. This raises a question for Papuans. Is there discrimination, such that not many Papuans can become high-ranking officers, such as a general? Up to now only three Papuans have ever attained the rank of general in the Indonesian Armed Forces (ABRI). And the same is true in other fields, too. The things that Papuans hope for or desire are still very far from being fulfilled, that is, their desire to progress and to enjoy the progress just as people in other areas in Indonesia do.

THE FIRST MAYOR OF JAYAPURA

In order to improve job performance, opportunities were opened for staff who were already employed as well as for young people to pursue continuing education in Java. Together with several friends, I was delegated by the local government to attend studies in the field of government administration, at the Academy for Domestic Government (APDN) in Malang.

After completing my studies at the APDN, I returned to my duties in Biak. And in Biak I was appointed as the head of the Bagian Umum dan Pembangunan (Division of Public Affairs and Development) to carry out government duties in the kabupaten of Biak-Numfor for three years. After that, I was assigned to return to attending studies at the Institut Ilmu Pemerintahan (IIP, Institute of Government Studies) in Malang for three years. And following completion of those studies in 1973, I returned to 
Irian Jaya and worked at the office of the governor of Jayapura as an official of the Regional Secretariat of the province of Irian Jaya for a year.

In 1974 I moved from Jayapura to Biak. I held the position of sekwilda (regional secretary) of Biak-Numfor for five years. Then, at the beginning of 1979 I was appointed by the governor to work at the Biro Pemerintahan (Administrative Bureau) in Jayapura, and served as the deputy head of the Bureau of Administration at the office of the governor of Irian Jaya for six months. Then, in September 1979 I was appointed as the first mayor of Jayapura.

Up until then, in the history of governance of Papua, no administrative city or municipal-level government had ever been established. The first time one was established in Irian Jaya was in 1979, and I was appointed to serve as the mayor for the administrative city of Jayapura. I held that position for ten years. And in those ten years we prepared all the existing facilities - first, office facilities, and then the employees and financial resources necessary to finance the administration. Then the status of the city was changed to that of a kota madya (municipality). Being a municipality meant having its own Council of Representatives. The whole process took a fairly long time - ten years - but it formed the embryo for the subsequent development of Jayapura municipality today.

At that time there was collaboration among the municipalities in Indonesia. There was also some collaboration with foreign municipalities, albeit limited in frequency. It was limited because the political situation and state of governance at the time was authoritarian. So local governments did not have the freedom to engage in relations with similar levels of government abroad. Now that, with further development, a democratic government has begun to appear, better possibilities will open for local governments to build more open, cooperative relationships with local governments abroad. Possibilities for that will open once the state passes new laws and regulations giving broad autonomy to the regions.

I prepared the city of Jayapura to be an administrative city and later, a municipality. But time kept moving on. I was getting older and approaching retirement age. So in 1989 I ended my term of service as the mayor of Jayapura and retired. All of my tasks and responsibilities were handed over to subsequent officials to build the city of Jayapura, which is now well-developed and expected to become even better in times to come. 
For me, the time of retirement or no longer being actively employed was not an impediment, not a time to do nothing. I felt I could probably contribute my thoughts or something that was not tangible, but could be felt by the community and by the Papuan people here. During my retirement I was aware of the existing reality, that there were still so many efforts that Papuans still had to make in order to move forward. Because of the experiences and events I have mentioned above, such as the Indonesian Communist Party rebellion, and the authoritarian government regime, the situation in Papua had worsened. The community had been put under pressure, rendered nearly powerless to speak, unable to confront anything.

In recent times, that is, in the past two years, the Indonesian government situation has changed. It appears that the authoritarian government is not wanted anymore. During the authoritarian government period, many things were controlled by personnel who were mostly from the military, which put pressures on the community, so people were not free to do much. Those were the circumstances that made society rise up to change the situation, in the reform period now known as Reformasi.

Reformasi has brought about changes in the government. Democracy has begun to emerge, meaning that the people are becoming involved in the governance process. In the Reformasi world, the people have begun to move forward. The former system of governance in Indonesia - which was run by only three political parties and one military element, so that there were only four socio-political groups in the Dewan Perwakilan Rakyat (DPR, Provincial House of People's Representatives) - has been revoked, and many new parties have formed. In the general election in 1999, democracy was truly implemented, and it was accompanied by more than three political parties.

That is what has made it possible for many people who formerly wanted to do something for society to act; now they are able to get into political parties for the people to elect, and become members of the DPR. I myself was elected to be a member of a newly formed political party, namely, the Partai Demokrasi Kasih Bangsa (PDKB, Love the Nation Democratic Party), which ranked third among the existing political parties in the number of votes it received. There are 11 political parties in Papua, and the one that ranked third was the PDKB. 
The PDKB has a tripartite vision and mission, or three main programmes regarding what we should struggle for in the process of democracy and governance. The first concerns human rights violations. This has not only to do with the killings, but also with the right to speak, the right to express opinions, the right to live and other rights that constitute the first programme this party stands for. The second concerns the natural environment, how to conserve the environment well, not only for the present generation but also for future generations. The third is democracy. Up to now democracy has been put under pressure by the government and the rulers. But the PDKB calls for a democracy that is truly implemented by everyone, so that good governance can be attained and everyone is allowed to speak and express their views in a democratic manner in the interests of all people. Those are the three basic programmes of the PDKB.

In the DPRD, there are six commissions, namely, the A Commission, B Commission, C Commission, D Commission, E Commission and F Commission. In the course of the distribution of tasks, as a member of the DPRD I became a member of the E Commission (public welfare). This Public Welfare Commission has the duty to absorb, listen to and negotiate with parties who look after religion, health, education, labour, the role of women and women's affairs, youth affairs, sports and family planning. Those are the duties of the $\mathrm{E}$ Commission. It works in all these areas to provide welfare to the community, so people can live good and decent lives as human beings.

The DPR of the province of Irian Jaya or Papua consists of 45 members, including a chairperson and three deputy chairpersons. The parties making up the provincial DPR in 1999 are: 1. Partai Golongan Karya (Golkar, Party of the Functional Groups), 2. Partai Demokrasi Indonesia Perjuangan (PDIP, Indonesian Democratic Party of Struggle), 3. Partai Demokrasi Kasih Bangsa (PDKB, Love the Nation Democratic Party), 4. Partai Demokrasi Indonesia (PDI, Indonesian Democratic Party), 5. Partai Kristen Nasional (PKN, National Christian Party), 6. Partai Katolik Demokrat (PKD, Democratic Catholic Party), 7. Partai Persatuan Pembangunan (PPP, United Development Party), 8. Partai Bulan Bintang (PBB, Crescent Star Party), 9. Partai Amanat Nasional (PAN, National Mandate Party), 10. Partai Kebangkitan Bangsa (PKB, National Awakening Party), 11. Partai Daulat Rakyat (PDR, People's Sovereignty Party), and 12. Partai Tentara Nasional Indonesia dan Polisi (Indonesian National Army and Police Party). 
Because it is the will of the people of Papua that the name Irian Jaya be changed to Papua, the name Papua is being legally processed to obtain a government decree. And to this end, the DPRD has formed a special committee, called the Special Committee to Change the Name of Irian Jaya to Papua. And this special committee has entrusted me as its chairman to prepare the report to be submitted to a parliamentary session (DPRD Level I) to determine the name of Papua. This process is expected to happen in August 2000. Then the DPRD will issue a decision that will be in turn submitted to the central government, which will issue a government ordinance on the change of the name Irian Jaya to Papua.

Why does the name Irian Jaya need to be replaced? It is because up until now, the name of Papua has been changed over and over again according to the taste of each government and its officials. Whereas Papua is the original name of the land and people of Papua. For many years, the Papua name has not been used because of political interventions by various nations and outside influences. But now the Papuans themselves understand and realize that this is our original name. Now Papuans want the name Papua to be restored. It is expected that this coming August, the name Papua will be definitely and publicly used, both by Papuans as well as by the whole Indonesian and world community, as the original name of the land and people of Papua.

Regarding autonomy for the region of Irian Jaya, the Indonesian government has taken a stand to increase the autonomy of Irian Jaya. Laws on autonomy were created in 1969, but autonomy did not operate; it was not carried out as it should have been. Now the Indonesian government wants to create one law on autonomy, so that autonomy can be implemented as well as possible for Papua along with other provinces. To Papua, special autonomy will be granted. Under special autonomy, arrangements will be made regarding the special characteristics and circumstances of the Papuan people. With autonomy it is expected that the government will run better. Under autonomy arrangements will also be made around the budget and finances for the Papuan region. Up to now, the budget has been determined by the central government. So it has remained for the regions to accept whatever amount is given to them. But hopefully, with the upcoming autonomy laws, it will be the regions that determine the size of the budget needed to meet local needs. 
Papua, with its existing potential, is the most highly productive region in Indonesia. For one thing, the mining company in Tembagapura is the company that provides the largest amount of money to the Republic of Indonesia. But of the money that the riches of Irian Jaya provide to the central government, only a very small amount is allotted for Papua and its people. Now, once autonomy is up and running, it is expected that the finances for Irian Jaya will change; revenues will be divided up with 20 percent for the central government and 80 percent for the regional government. Up to now the division has been 95 percent for the centre and five percent for the region. This is what has prevented Papuans from enjoying much progress. The DPRD will struggle with the central government to ensure that the division of finances is set at 80 percent for the region and 20 percent for the centre. In the laws on special autonomy, it must be stipulated that regional finances should be organized that way. There are hopes that finances for the region will change starting from the coming year onwards, so that the people can advance, to move forward better than ever before. 